\title{
Development of Cream Soup Product Made from Combination of Black Soybean (Glycine soja L. merrit) and Red Rice (Oryza nivara) as an Alternative Functional Food for Menopausal Women
}

\author{
Wiwit Estuti $^{*}$, Sri Anna Marliyati², Muhammad Rizal Martua Damanik², \\ Budi Setiawan $^{2}$ \\ ${ }^{1}$ Nutrition Major of Tasikmalaya Health Polytechnic of the Ministry of Health, Tasikmalaya 45132 \\ ${ }^{2}$ Department of Community Nutrition, Faculty of Human Ecology, Bogor Agricultural University, \\ Bogor 16680
}

\begin{abstract}
This study aimed to develop an organoleptic acceptable cream soup formula made from combination of black soybean (Glycine soja L. merrit) and red rice (Oryza nivara) which met the nutritional requirements and contained antioxidants in the form of snack as a functional food for menopausal women. This study used a completely randomized design (CRD) with three treatment levels combination of black soybeans and red rice, namely F1 (80:20), F2 (70:30), and F3 (60:40). The results of the hedonic organoleptic test showed that the selected formula was F1 functional cream soup product. The nutrient content analysis showed that the product contained $1.98 \%$ water, $1.88 \%$ ash, $4.00 \%$ fat, $13.36 \%$ protein, $78.76 \%$ carbohydrates, $17.87 \%$ total dietary fiber, $10.71 \%$ soluble dietary fiber, $162.59 \mu \mathrm{g} / \mathrm{g}$ total isoflavones, and $254.58 \mu \mathrm{g} / \mathrm{g}$ total anthocyanins. Each portion of the F1 product could contribute $10.66 \%$ and $11.73 \%$ of the recommended dietary allowances (RDA) for energy and protein for women of menopausal age, respectively. Each portion also had an antioxidant activity of $723.73 \mathrm{mg} / 100 \mathrm{~g}$ (AEAC). The product is safe to consume because its total microbial content was $3.4 \times 10^{2}$ colonies $/ \mathrm{g}$. The resulting product has the potential to be a functional food due to its fiber, total isoflavones, and total anthocyanins contents, as well as its antioxidant activity.
\end{abstract}

Keywords: black soybean, cream soup, functional food, menopause

\section{INTRODUCTION}

Menopause period is a natural physiological process in women which occurs at the age of about 45-55 years, characterized by permanent cessation of menstruation caused by the ovarian failure to produce ovum and related hormones (Sturdee 2014). Menopausal women are 1.36 times at higher risk of having degenerative diseases (especially cardiovascular disease) than premenopausal women (Femke et al. 2006) and the risk will continue to increase in postmenopausal women for 2-3 years (He et al. 2012).

One of the pathophysiology for this increasing risk for degenerative disease in menopausal women is trough oxidative stress. Oxidative stress is an imbalance condition between free radicals in the tissues, reactive oxygen species (ROS), and antioxidant levels. It is caused by the release of ROS in various tissues and it develops into various menopausal symptoms and pathological conditions, especially cardiovascu- lar disease (Doshi \& Agarwal 2013). The damage cause by free radical or lipid peroxidation activities can be observed by the presence of malondialdehyde (MDA) indicator in the blood (Mark et al. 2000). In addition, oxidative stress can also be indicated by low antioxidant status and superoxide dismutase (SOD) as a marker for primary antioxidants (Vetrani et al. 2013).

Intervention strategies that can be conducted to repair the lipid profile damaged by free radicals and to control oxidative stress is through diet modification. Several studies have confirmed that the consumption of high antioxidant food products are able to inhibit lipid peroxidation and increase antioxidant enzymes (Vincent et al. 2007). Black soybean (Glycine soja L. merrit) is a type of legumes that has the capacity as a highly nutritious food source as well as contains functional components (i.e. anthocyanin) which is not found in other types of soybeans. The anthocyanins such as found in black soybean has the ability to catch free radicals, inhibit lipid peroxidation pro-

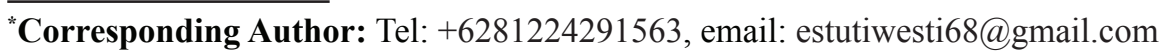


cess, and inhibit DNA damage (Byun et al. 2010). Thus, the black soybean is useful for menopausal women who have predisposing factors for oxidative stress due to the absence of estrogen (Mendoza \& Zamarripa 2013).

In addition to black soybeans, the food that has high potential but is still rarely utilized is red rice. The red rice contains lower amounts of calories than white rice (USDA 2007). It also contains protein, beta-carotene, antioxidants, iron, and fiber (Frei 2004). The antioxidants in the red rice derived from anthocyanin pigments that can prevent coronary heart disease, cancer, diabetes, and hypertension (Astawan 2009; Suardi 2005; Kasim et al. 2005).

On top of its high antioxidant content, black soybeans also contain a high source of plant-based protein (i.e. lysine) but have a small amount of limiting amino acids such as methionine and cysteine. The lack of methionine and cysteine in black soybeans can be complemented by the red rice which is high in methionine and cysteine but low in lysine. The combination of black soybeans and red rice can complement the amino acid contents of both foodstuffs as functional food products.

The development of functional food in the form of snacks for women of menopausal age has not been widely studied. The available black soybean snacks found to be limited to black soybean milk and in the form of snack bar made from sweet potatoes and black soybeans (Sabuluntika \& Ayustaningwarno 2014). Thus, it is important to develop alternative functional food products as instant snacks from local foods which meet the nutritional requirements of menopausal women and have antioxidant activity. Cream soup can be an alternative form of the instant food product, it allows the combination of black soybeans and red rice, thereby increasing the functional value of the product due to the bioactive components in it.

The aim of this study was to develop a cream soup formula made from a combination of black soybeans and red rice that is acceptable based on organoleptic test. In addition to that, the food formula is expected to meet the nutritional requirements for energy and protein as well as contains high antioxidants as a functional snack product designed for menopausal women.

\section{METHODS}

\section{Design, location, and time}

This study used a Completely Randomized Design(CRD) which combined black soybeans and red rice comprising of three treatments levels; i.e. F1 (80:20), F2 (70:30), and F3 (60:40). This study was conducted from March to October 2017. The product development, cream soup making in Pilot Plan Laboratory "Southeast Asia Food and Agricultural Science and Technology Center" (SEAFAST Center) and Techno Park. The preparation of the materials needed in Food Testing Laboratory, Antioxidant analysis in Laboratory of Nutritional and Biochemistry, Organoleptic analysis in Sensory Analysis Laboratory of the Department of Community Nutrition, Faculty of Human Ecology, Bogor Agricultural University, and proximate analysis (water content, ash content, protein, fat and carbohydrate) as well as fiber content analysis in Laboratory of Chemistry and Microbiology, Malang Muhammadyah University, East Java.

\section{Materials and tools}

The raw materials used in the cream soup production were Detam-1 black soybeans from the Research Station for Legumes and Tubers (BALITKABI), East Java and Inpari 24 red rice obtained from the Research Station for Rice (BALITPADI) in Sukamandi, Subang, West Java. The complementary ingredients for the cream soup production were chicken broth, skimmed milk, margarine, carrots, onions, garlic, scallion, celery, pepper, salt, granulated sugar, and bay leaves. Chemicals used in proximate analysis are selenium, strong $\mathrm{H}_{2} \mathrm{SO}_{4}$, aquades, NAOH $40 \%$, boric acid $\left(\mathrm{H}_{3} \mathrm{BO}_{3}\right) 2 \%$, methyl red indicator, HCL $0.1 \mathrm{~N}$, and hexane. Dietary fiber analysis used buffer solution $\mathrm{pH} 8.2$, alfa-amylase, protease, HCL, amyloglukosidase, ethanol $95 \%$ and $78 \%$, aceton. Total isoflavones analysis used standard solution of deidzein and genestein, orthophosphate acid $0,1 \%$ in aquades and acetonitrile $25 \%(1: 1)$. Total anthocyanin analysis used $\mathrm{HCl} 0.1 \%$, methanol, buffer solution $\mathrm{pH} 1$. Antioxidant activity analysis used 1.1-diphenyl2-2-diphierylhydrazil (DPPH), vitamin C, Total Plate Counts (TPC) total microbes analysis used Plate Count Agar (PCA) media.

The instruments used in this study were 1) tools for making the functional cream soup: pot, stove, blender, knife, cutting board, spoon, spatula, drum dryer, bean grinder machine, and steam jacket; 2) tools for chemical analysis: analytical balance, porcelain and aluminium dishes, volumetric flask, micropipettes, Mohr pipettes, test tube, Whatman filter paper, Erlenmeyer flask, boiling flask, Kjeldahl flask, Soxhlet extractor, furnace, oven, Bunsen burner, beaker glass, dis- 
tillation apparatus, incubator, vortex mixer, vacuum filter, magnetic stirrer, centrifuge, evaporator, and UV-Vis spectrophotometer; 3) tools for organoleptic test: plastic cup and serving plate.

\section{Procedures}

This study was initiated by making cream soup formulation and production process. The organoleptic test was then performed to select the product. The selected product then further analyzed to establish the nutrient content, total isoflavones, total anthocyanins, total dietary fiber, antioxidant activity, and total microbes of the selected cream soup. Next, the nutrient contribution of the functional cream soup to the Recommended Dietary Allowances (RDA) for menopausal women (50-60 years) was calculated.

Ingredient formulation and production process of cream soup as a functional food. The cream soup formulation was conducted in two phases. The first phase was calculating the ratio of black soybeans to red rice that could reach the amino acid scores of 90-100. The second phase was calculating the macronutrient contents based on the upper limit and lower limit of the RDA for menopausal women. The formula determination was also performed by trial and error. The formula ratio of black soybeans to red rice obtained in this study were F1 (80:20), F2 (70:30), and F3 (60:40). Table 1 shows the cream soup formulas.

The cream soup production consisted of several stages, i.e., preparation, processing, drying, and dry mixing. It began with the preparation of the ingredients (i.e., peeling and cutting the ingredients used), sautéed the spices used which consisted of onions, garlic, sugar, celery, and spring onion, as well as the chicken stock preparation. After that, the black soybeans were soaked for 12 hours in advance. In parallel, the red rice was made into flour before being processed. The black soybeans were soaked, the water was discarded, and they were washed thoroughly. After that, the black soybeans were boiled for $30 \mathrm{mi}-$ nutes, put into the soybean grinder, and grounded into black soybean porridge (water to soybeans ratio of 1:4). The black soybean porridge was then cooked in the steam jacket, and the red rice flour was added. It was stirred continuously until boiling. Meanwhile, the sautéed spices were added to the steam jacket containing the black soybeans and red rice flour while stirring constantly. The chicken broth that had been prepared was then put into the soup and cooked for 30 minutes until thickened. The next stage was the production of instant cream soup by drying using a drum dryer. The drum dryer was used to dry the ingredients in the form of paste or solution. The drum rotated on a horizontal axis, and it was heated internally with hot steam or another hot medium (Brennan et al. 1974). Before the drying process, the parameters of the process affecting the characteristics of the resulting product were adjusted beforehand. The boiler pressure was set at two bars, and the cylinder rotation was set at three revolutions per minute (rpm). A study conducted by Ardiansyah (2014) suggested that the parameters of the process affecting the final product needed to be adjusted to maximize the yield of the dried products so that not much was wasted and the optimal instant cream soup was produced. The cream soup that had been thickened was then cooled. The cream soup was dried using

Table 1. Formulation of a cream soup made from a combination of black soybeans and red rice

\begin{tabular}{lccc}
\hline \multirow{2}{*}{ Ingredients } & \multicolumn{3}{c}{ Ingredient weight } \\
\cline { 2 - 4 } & $\mathrm{F} 1$ & $\mathrm{~F} 2$ & $\mathrm{~F} 3$ \\
\hline Black soybeans $(\mathrm{g})$ & 10.41 & 9.11 & 7.80 \\
Red rice (g) & 2.60 & 3.90 & 5.20 \\
Chicken broth (ml) & 26.02 & 26.02 & 26.02 \\
Carrots (g) & 1.30 & 1.30 & 1.30 \\
Skim milk (g) & 1.30 & 1.30 & 1.30 \\
Margarine (g) & 1.30 & 1.30 & 1.30 \\
Onion (g) & 1.95 & 1.95 & 1.95 \\
Garlic (g) & 0.39 & 0.39 & 0.39 \\
Scallion (g) & 0.65 & 0.65 & 0.65 \\
Pepper (g) & 0.10 & 0.10 & 0.10 \\
Celery (g) & 0.33 & 0.33 & 0.33 \\
Salt (g) & 0.33 & 0.33 & 0.33 \\
Granulated sugar (g) & 1.30 & 1.30 & 1.30 \\
Water (ml) & 52.03 & 1.30 & 100.00 \\
Total dough & 100.00 & 100.00 & \\
\hline
\end{tabular}


a drum dryer. The dry mixing was performed for the ingredients such as skim milk and salt. The cream soup was then put in a small sealed package made from aluminium foil.

Analysis of the organoleptic properties of the cream soup as a functional food product. The organoleptic test of the selected cream soup utilized the hedonic (preference) test. Setyaningsih et al. (2010) stated that the hedonic test was performed to find out the panelists' impression of the food product properties. The organoleptic test was performed on 25 semi-trained panelists. The panelists were students of the Department of Community Nutrition, Faculty of Human Ecology, Bogor Agricultural University. The analysis of the organoleptic properties of the cream soup as a functional food was conducted using a 10-cm hybrid scale. The test used 1-9 line scales. The parameters of the hedonic test of the cream soup were color, smell, taste, texture, and overall assessment. The scales used in these parameters were as follows: (1) dislike extremely, (2) dislike very much, (3) dislike moderately, (4) dislike slightly, (5) neither dislike nor like, (6) like slightly, (7) like moderately, (8) like very much, and (9) like extremely. The panelist was deemed to accept the product sample if the given value was greater than 5 .

The panelist's preference on the overall product was obtained based on the sum of the panelists' assessment scores with the percentages as follows: $20 \%$ of the color score, $25 \%$ of the smell score, $35 \%$ of the taste score, and $20 \%$ of the texture score. The percentage of the panelists' product acceptance was calculated based on the ratio panelists who gave scales (6) like slightly, (7) like moderately, (8) like very much, and (9) like extremely to the total panelists. One formula was then selected as the best product based on this organoleptic test.

Analysis of the cream soup as the selected functional food product. The proximate analysis (water, ash, fat, protein, and carbohydrates) along with the analysis of total isoflavones, total anthocyanins, total dietary fiber, antioxidant activity, and total microbes were then performed on a single formula that was selected based on the organoleptic test results. The analysis of water content (gravimetric method), ash content (dry ashing method), and fat content (Soxhlet method) were performed according to SNI 012891-1992 (SNI 1992) while the protein content analysis (micro-Kjeldahl method) was performed in accordance with AOAC 960.52-1961 (AOAC 2010). The carbohydrate content was calculated by difference. Total dietary fiber analysis (enzymatic method) was conducted in accordance with AOAC 985.29.2005 (AOAC 2005). Total anthocyanin content was analyzed using AOAC Official Method 2005.2 with HPLC, total isoflavones were analyzed by HPLC method, and total microbial analysis was performed by using total plate count method at $30^{\circ} \mathrm{C}$ for 72 hours (SNI 2008). Total antioxidant activity was assessed by DPPH scavenging activity method and expressed in ascorbic acid equivalent antioxidant capacity (AEAC) (Kubo et al. 2002; Damayanthi et al. 2010). The nutrient contribution to the RDA of menopausal women (50-60 years) included energy, protein, fat, carbohydrates, and dietary fiber. The RDAs referred to the 2013 Indonesian RDA.

\section{Data analysis}

Descriptive statistics and one-way ANOVA were performed to analyze the data regarding organoleptic properties. Nutritional content, total isoflavones, total anthocyanins, total dietary fiber, antioxidant activity, total microbes, and nutritional contributions of the selected formula were tabulated and analyzed descriptively. The data were processed using 2010 Microsoft Excel and SPSS version 23.0 for Windows.

\section{RESULTS AND DISCUSSION}

\section{The results of organoleptic properties analy- sis of cream soup as a functional food}

The analysis of the organoleptic properties of the cream soup performed in this study was the hedonic (preference) test. The hedonic test attributes were color, smell, taste, and texture. The data on the organoleptic properties of the cream soup product are presented in Table 2. It can be seen that the percentage of panelist acceptance on the organoleptic properties of the products (F1, $\mathrm{F} 2$, and F3) ranged from $50.00 \%$ to $96.15 \%$. The data in Table 3 indicates that F1 is the most acceptable product based on its organoleptic properties (taste, texture, and overall properties). F1 had a composition ratio of $80 \%$ black soybeans and $20 \%$ red rice. It had the following composition: $10.41 \%$ black soybeans, $2.60 \%$ red rice, $26.02 \%$ chicken broth, $1.30 \%$ carrot, $1.30 \%$ skim milk, $1.30 \%$ margarine, $1.95 \%$ onion, $0.39 \%$ garlic, $0.65 \%$ spring onion, $0.10 \%$ pepper, $0.33 \%$ celery, $0.33 \%$ salt, $1.30 \%$ sugar, and $52.03 \%$ water.

This study showed that the mean values of the panelists' preference for color, smell, taste, texture, and overall properties of the products 
Table 2. Percentage of panelists' acceptance on the organoleptic properties of the cream soup as an alternative functional food based on product type (\%)

\begin{tabular}{cccccc}
\hline \multirow{2}{*}{ Types of product } & \multicolumn{5}{c}{ Organoleptic properties } \\
\cline { 2 - 6 } & Color & Smell & Taste & Texture & Overall \\
\hline F1 & 69.23 & 80.77 & 80.77 & 84.62 & 80.77 \\
F2 & 76.92 & 76.92 & 57.69 & 61.54 & 65.38 \\
F3 & 50.00 & 96.15 & 73.08 & 57.69 & 73.08 \\
\hline
\end{tabular}

were not significantly different $(p>0.05)$. The results indicated that there was no significant effect of F1, F2, and F3 treatment levels on the color, smell, taste, texture, and the overall properties of the product. The data in Table 3 shows that the mean values of the panelists' preference for color, taste, and the overall properties of the F1 product are significantly higher than those of F2 and F3 products. The mean values of the panelists' preference for color, smell, taste, texture, and the overall properties were 6.24 (like slightly), 7.00 (like moderately), 6.78 (like moderately), 7.37 (like moderately), and 6.90 (like moderately), respectively. The product can be described as having a slightly brownish color, distinctive smell of black soybeans and red rice mixture, salty and savory taste. The figures followed by different letters in the same column showed a significant difference between treatment levels $(p<0.05)$ (Table $3)$.

Table 3. Panelists' mean hedonic scales of organoleptic properties of the cream soup as an alternative functional food based on product type

\begin{tabular}{cccccc}
\hline \multirow{2}{*}{ Types of product } & \multicolumn{5}{c}{ Organoleptic properties } \\
\cline { 2 - 6 } & Color & Smell & Taste & Texture & Overall \\
\hline F1 & $6.24^{\mathrm{a}}$ & $7.00^{\mathrm{a}}$ & $6.78^{\mathrm{a}}$ & $7.37^{\mathrm{a}}$ & $6.90^{\mathrm{a}}$ \\
F2 & $6.40^{\mathrm{a}}$ & $6.10^{\mathrm{a}}$ & $5.47^{\mathrm{a}}$ & $6.07^{\mathrm{a}}$ & $5.91^{\mathrm{a}}$ \\
F3 & $5.46^{\mathrm{a}}$ & $7.21^{\mathrm{a}}$ & $6.64^{\mathrm{a}}$ & $5.84^{\mathrm{a}}$ & $6.41^{\mathrm{a}}$ \\
\hline
\end{tabular}

Notes: attribute scales, from 1 (dislike extremely) to 9 (like extremely)

Table 4. Nutrient content, total isoflavones, total anthocyanins, antioxidant activity, and total microbes of the cream soup as the selected functional product

\begin{tabular}{|c|c|}
\hline The tested characteristics & Total \\
\hline Water (\%) & 1.98 \\
\hline Ash (\%) & 1.88 \\
\hline Fat $(\%)$ & 4.00 \\
\hline Protein $(\%)$ & 13.36 \\
\hline Carbohydrates (\%) & 78.76 \\
\hline Energy (kcal) & 404.92 \\
\hline Total dietary fiber $(\mathrm{g})$ & 17.87 \\
\hline Total isoflavones $(\mu \mathrm{g} / \mathrm{g})$ & 162.6 \\
\hline Total anthocyanins $(\mu \mathrm{g} / \mathrm{g})$ & 254.58 \\
\hline Total microbes (Total plate count) (colony/g) & $3.4 \times 10^{2}$ \\
\hline Antioxidant activity $(\mathrm{mg} / 100 \mathrm{~g})$ & 723.73 \\
\hline
\end{tabular}

Nutrient content, total isoflavones, total anthocyanins, antioxidant activity, and total microbes of the cream soup as the selected functional product

The nutrient content, total isoflavones, total anthocyanins, antioxidant activity, and total microbes of the selected cream soup are presented in Table 4. The selected product had a water content of $1.98 \%$. The water content has met the quality requirement of SNI 01-4967-199 (maximum limit of $8 \%$ ). The ash content obtained from the cream soup analysis was $1.88 \%$. The mineral content in the combined cream soup product is assumed to be derived from the black soybeans and red rice which are rich in minerals such as phosphorus, calcium, and iron. The calcium in the product also might come from the skimmed milk. The fat content obtained from the analysis of the cream soup was $4.00 \%$. This 
value is slightly lower than the quality requirement of SNI 01-4967-1999 (minimum limit of $5 \%$ ). The fat source in the combined cream soup is assumed to come from margarine, broth, and black soybeans.

The protein content obtained from the analysis of the selected cream soup was $13.36 \%$. The value has met the quality requirement of SNI 01-4967-1999 (minimum limit of 10\%). The combined cream soup can be claimed as a protein source because it fulfills the requirement of $\operatorname{BPOM}(2016)$ that a food product can be declared as a "protein source" if it contains no less than $20 \%$ of the Nutrition Label References per 100 $\mathrm{g}$ in solid form. The carbohydrate content was obtained by carbohydrate by difference method, thereby the water, ash, protein, and fat contents greatly affected the carbohydrate content in the combined cream soup. The carbohydrate content acquired based on this method was $78.76 \%$. The amount of carbohydrate content in the product may originated from chosen raw ingredient of the selected cream soup (i.e. red rice) which is a source of carbohydrates. In addition to the red rice, other ingredients such as skim milk, black soybeans, and sugar also contribute to the carbohydrate content.

The main ingredients of the selected cream soup formula were black soybeans and red rice. Black soybean (Glycine soja L. Merrit) is a type of grain which has sufficient nutritional contents, especially protein. It contains complex carbohydrates, plant-based protein, fiber, oligosaccharides, isoflavones, and complex minerals. The fiber content may contributes to weight loss, in which weight gain is a common problem during menopause period. The nutritional composition of dried black soybeans consists of protein (420 $\mathrm{mg} / \mathrm{g})$, fat $(224 \mathrm{mg} / \mathrm{g})$, carbohydrates $(340 \mathrm{mg} / \mathrm{g})$, calcium $(6 \mathrm{mg} / \mathrm{g})$, phosphorus $(5 \mathrm{mg} / \mathrm{g})$, and iron $(0.1 \mathrm{mg} / \mathrm{g})$ (Nurrahman 2015).

Red rice is a grain that contains a lot of bioactive polyphenols. In rice, these polyphenols are widely contained in the bran layer and much is lost in the milling process. Rice contains phenolic substances (i.e. ferulic acid and p-coumaric acid) in large quantities in soluble free, soluble conjugate, and insoluble-bound forms that can be found in dietary fiber (Tian et al. 2004). Several studies have shown that the red rice and black rice are able to reduce $50 \%$ of atherosclerotic plaque, ROS, and MDA as well as significantly increase the HDL-c and APO A-1 concentrations in rabbits compared to white rice (Ling et al. 2001).
The selected product contained $17,87 \%$ of total dietary fiber and $10,71 \%$ dietary soluble fiber. This combined cream soup product can be claimed as high in fiber because it meets the requirement of BPOM (2016) that a food product is "high in fiber" if it contains $6 \mathrm{~g}$ fiber $/ 100 \mathrm{~g}$ in solid form. Dietary fiber has a good physiological effect on digestion (Darawati et al. 2016). Sufficient consumption of dietary fiber is good for menopausal women. Fiber can lower blood cholesterol levels by binding bile acids, thereby increasing the release of bile acids in feces (Eshak et al. 2010).

The total isoflavones in the combined cream soup product was $16.59 \mu \mathrm{g} / \mathrm{g}$ soy protein. The consumption of soy products has been linked to a decrease in the incidence or severity of chronic diseases such as cardiovascular cancer, breast cancer, prostate cancer, menopausal symptoms, and osteoporosis. Total anthocyanins of the selected product was $254.58 \mu \mathrm{g} / \mathrm{g}$. The antioxidant activity of anthocyanin in the black soybeans (cyanidine-3-glucoside) can decrease LDL-c, increase HDL-c, inhibit LDL-c oxidation, and reduce the body fat accumulation because it suppresses the lipid synthesis in the liver and adipose (Bhuiyan et al. 2011). The antioxidant activity of the product measured by DPPH method was $723.73 \mathrm{mg} / 100 \mathrm{~g}$ (AEAC = ascorbic acid equivalent antioxidant capacity) or comparable to vit $\mathrm{C}$ antioxidant capacity (Leong \& Shui 2002). Total microbes in the functional cream soup were $3.4 \times 10^{2}$ colonies/g which were still below the threshold for such processed product $\left(1 \times 10^{4}\right.$ colonies $\left./ \mathrm{g}\right)$, thereby this functional cream soup is safe for consumption (BPOM 2009).

The energy content in $100 \mathrm{~g}$ of the selected cream soup was $404.92 \mathrm{kcal}$, thereby one serving $(50 \mathrm{~g})$ of the soup had $202.46 \mathrm{kcal}$ which was estimated from the following sum: (4 x protein content $)+(9 \mathrm{x}$ fat content $)+(4 \mathrm{x}$ carbohydrate content). Meanwhile, the protein content was 13,36\%. According to Kemenkes RI (2013), the daily energy and protein requirements of menopausal women are $1900 \mathrm{kcal}$ and $57 \mathrm{~g}$, respectively. Thus, the energy content $(10.66 \%)$ and protein content $(11.72 \%)$ of the selected cream soup product can help meet the total daily requirement of the menopausal women. Therefore, the selected product (F1) has several advantages. It contains energy and protein that can help meet the nutritional requirement of the menopausal women $(10.66 \%$ of total energy requirement and $12.37 \%$ of protein requirement). It has favorable 
and acceptable organoleptic properties and has high fiber content. It also contains isoflavones and anthocyanins as antioxidant.

\section{CONCLUSION}

The F1 cream soup was the selected product based on the organoleptic properties with nutrient contents as follows: $1.98 \%$ water, $1.88 \%$ ash, $13.36 \%$ protein, $4.00 \%$ fat, $78.76 \%$ carbohydrates, $404.92 \mathrm{kcal}, 17.87 \mathrm{~g}$ total dietary fiber, and $10.71 \mathrm{~g}$ soluble fiber. It also contains 162.59 $\mu \mathrm{g} / \mathrm{g}$ protein of total isoflavones, $254.58 \mu \mathrm{g} / \mathrm{g}$ of total anthocyanins, $723.73 \mathrm{mg} / 100 \mathrm{~g}$ antioxidant activity, and $3.4 \times 10^{2}$ colonies/g total microbes. The F1 product contains energy and protein that can help meet the nutritional requirements of menopausal women; i.e. $10.66 \%$ of the energy requirement and $12.37 \%$ of the protein requirement.the nutrition content in this product has fullfilled the requirement of SNI 01-4967-1999 except for fat content that is lower. This product has potential as a functional food because it contains isoflavones, anthocyanins, high in fiber and has antioxidant activity. This product can also be considered as a snack for menopausal women. This combined cream soup can also be developed into a fresh and long-lasting cream soup which can be warmed using a microwave in the jar form whenever we want to consume it.

\section{ACKNOWLEDGEMENTS}

The authors would like to thanks the $\mathrm{Hu}-$ man Resources Development Board of the Ministry of Health of the Republic of Indonesia who has funded the education and research during when the author underwent the doctoral program in Nutrition Science Program, Department of Community Nutrition, Faculty of Human Ecology, Bogor Agricultural University, Bogor, Indonesia.

\section{REFERENCES}

Ardiansyah. 2014. Pemanfaatan pati ubi jalar (Ipmoea batatas) dalam produk sup instan jamur kuping (Auricularia auricula) [Skripsi]. Bogor: Institut Pertanian Bogor.

[AOAC] Association of Official Analytical Chemist. 2005. Total dietary fiber determinanation. AOAC 985.29. Washington DC: Official Methodes of Analysis.
[AOAC] Association of Official Analytical Chemist. 2010. Microchemical determinat of Nitogen.

[AOAC] Association of official analytical chemist. 960.52-1961. Washington DC: Official Methodes of Analysis.

[AOAC] Association of Official Analytical Chemist. 2005. Official method of analysis: The association of official analytical chemist (18 ed.). Virginia: AOAC Inc.

Astawan M. 2009. Sehat dengan hidangan kacang dan biji-bijian. Jakarta: Penebar Swadaya.

Bhuiyan MIQ, Joo YK, Thae JH, Seong YK. 2011. Anthociyanins estracted from black soybean seed coat protect primary cortical neurons againts in vitro ischemia. Reguler Article. Biol. Pharm. Bull 35(7):999-1008.

[BPOM RI] Badan Pengawas Obat dan Makanan Republik Indonesia. 2009. Penetapan Batas Maksimum Cemaran Mikroba dan Kimia dalam Makanan. Jakarta: BPOM RI.

[BPOM RI] Badan Pengawas Obat dan Makanan Republik Indonesia. 2016. Pengawasan klaim pada label dan iklan pangan olahan No. 13 Tahun 2016. Jakarta: BPOM RI.

Brennan JG, Buthers JR, Cowel ND, Lily AV. 1974. Food Enginering Operation. London (UK): Applied Science Publisher Ltd.

Byun JS, Han YS, Lee SS. 2010. The effects of yellow soybeans, black soybeans, and sword bean on lipid levels and oxidative stress in ovariectomized rats. Int J Vitam Nutr Res 80(2):97-106.

Damayanthi E, Kustiyah L, Khalid M, Farizal H. 2010. Aktivitas antioksidan bekatul lebih tinggi daripada jus tomat dan penurunan aktivitas oksidan serum setelah intervensi minuman kaya antioksidan. J. Gizi Pangan 5(3):205-210.

Darawati M, Hadi R, Evy D, Lilik K. 2016. Pengembangan pangan fungsional berbasis pangan lokal sebagai produk sarapan untuk remaja gemuk. J Gizi Pangan 11(1):43-50.

Doshi SB, Agarwal A. 2013. The role of oxidative stress in menopause. J Midlife Health 4(3):140-146.

Eshak ES, Hiroyasu I, Chigusa D. 2010. Dietary fiber intake is associated with reduced risk of mortality from cardiovaskular disease among. Japanese Men and Wommen. J Nutri 140:1445-1453. 
Femke A, Marie-Louise ELB, Diederick EG, Yvonne TVDS. 2006. Postmenopausal status and early menopause as independent risk factors for cardiovascular disease: a meta-analysis. The Journal of The North American Menopause Society 13(2):265279.

Frei KB. 2004. Improving the nutrient availability in rice-biotechnology or bio-diversity. In A. Wilcke (Ed.) Agriculture and Development. Contributing to International Cooperation 11(2):64-65.

He L, Tang X, Li N, Wu YQ, Wang JW, Li JR, Zhang ZX, Dou HD, Liu JJ, Yu LP et al. 2012. Menopause with cardiovascular disease and its risk factors among rural Chinese women in Beijing: a populationbased study. Maturitas 72(2):132-138. Doi:10.1016/j.maturitas.2012.02.013.

Kasim E, Astuti S, Nurhidayat N. 2005. Karakterisasi pigmen dan kadar lovastatin beberapa isolat monascus purpureus. Biodiversitas 2466(4):245-247.

[Kemenkes RI]. Kementerian Kesehatan Republik Indonesia Republik Indonesia. 2013. Peraturan Menteri Kesehatan RI No. 75 tahun 2013 tentang Angka Kecukupan Gizi yang Dianjurkan bagi Bangsa Indonesia. Jakarta: Kementrian Kesehatan RI.

Kubo I, Masuda N, Xiao P, Haraguchi H. 2002. Antioxidant activity of deodecyl gallete. J Agric Food Chem 50:3533-3539.

Leong LP, Shui G, 2002 An Investigation of antioxidant capacity of fruit in Singapore markets. Food Chem 76:69-75.

Ling WH, Cheng QX, Ma J, Wang T. 2001. Red and black rice decrease atherosclerotic plaque formation and increase antioxidant status in rabbits. J Nutr 131(5):1421-1426.

Mark DB, Allan D Marks, Colleen M. Smith. 2000. Basic Medical Biochemistry: A Clinical Approach. Jakarta: Penerbit Buku Kedokteran

Mendoza CCC, Zamarippa CAJ. 2013. Menopause Induces Oxidative Stress. INTECH Open Access. available on : http://dx.doi. org/10.5772/52082.
Nurrahman. 2015. Evaluasi komposisi zat gizi dan senyawa antioksidan kedelai hitam dan kedelai kuning. Jurnal Aplikasi Teknologi Pangan 4(3):89-93.

Sabuluntika N, Ayustaningwarno F. 2014. Pengaruh variasi pemberian Snack bar ubi jalar kedelai hitam terhadap Kadar Superoksida Dismutase (SOD) darah. Jurnal Gizi Indonesia 3(1):20-25.

Setyaningsih D, Apriyantono A, Sari MP. 2010. Analisis sensori untuk industri pangan dan agro. Bogor: IPB-Press.

[SNI] Standar Nasional Indonesia. 1992. Cara Uji Makanan dan Minuman. SNI 01-28911992. Jakarta: Badan Standarisasi Nasional.

[SNI] Standar Nasional Indonesia. 1999. Syarat Sup Krim Instan. SNI 01-4967-1999. Bandung: BPOM.

[SNI] Standar Nasional Indonesia. 2008. Metode Pengujian Cemaran Mikroba pada Produk Olahan Pangan. SNI 2897. Jakarta: Badan Standarisasi Nasional.

Sturdee DW. 2014. Reference Module in Biomedical Sciences: Menopause. Elsevier.

Suardi DK. 2005. Potensi beras merah untuk peningkatan mutu pangan. JPPP 24(3):93-100.

Tian S, Nakamura K, Kayahara H. 2004. Analysis of phenolic compounds in white rice, brown rice, and germinated brown rice. J. Agric. Food Chem 52(13):4808-4813.

[USDA] United State Department of Agriculture. 2007. USDA commodity food fact sheet for school \& child nutrition institutions. [downloaded on Oktober 30th, 2016]. Available online: http://www.fns.usds. gov/fdd.

Vetrani C, Costabile G, Di-marino L, Rivellese AA. 2013. Nutrition and Oxidative stress: a systematic review of humans studes. Int $\mathbf{J}$ Food Sci and Nutr 64(3):312-326.

Vincent HK, Innes KE. Vincent KR. 2007. Oxidative stress and potensial interventions to reduce oxidative stress in overweight and obesity. J Compilation Blackwell Publishing Ltd. Diabetes, obesity and metabolism 9:813-839. 